\title{
Sprouting ability and mortality of chestnut (Castanea sativa Mill.) after coppicing. A case study
}

\author{
Fulvio GIUDICI ${ }^{\mathrm{a} *}$, Andreas ZINGG ${ }^{\mathrm{b}}$ \\ ${ }^{a}$ WSL, Swiss Federal Institute for Forest, Snow and Landscape Research, Sottostazione Sud delle Alpi, Bellinzona, Switzerland \\ ${ }^{\mathrm{b}}$ WSL, Swiss Federal Institute for Forest, Snow and Landscape Research, Birmensdorf, Switzerland
}

(Received 6 December 2004; accepted 16 March 2005)

\begin{abstract}
To study the sprouting ability of chestnut stands a 60 year old coppice stand in southern Switzerland was coppiced by removing all live and dead shoots. Two years and four years after coppicing surveys of the newly produced shoots was carried out in order to analyse growth and mortality of the young stand and to verify the factors influencing the sprouting ability. The mortality of stools was only $4 \%$; the number of produced shoots was, with 48 shoots per stool, high and the growth of the shoots was remarkable. Stand structure, stool density and the dimensions of the old stools neither reduced sprouting ability nor influenced the diameter and height growth, but the stump cut quality has a positive effect. Finally, height measurement of the dominant shoot on a stool provides a good indicator for the evaluation of the vigour of the regeneration in a chestnut coppice.
\end{abstract}

chestnut coppice / silviculture / competition / shoots and stool mortality

Résumé - Production de rejets et mortalité du châtaignier (Castanea sativa Mill.) après une coupe de taillis. Une étude de cas. Une étude sur la capacité à rejeter de souche du châtaignier (Castanea sativa Mill.) a été effectuée dans un taillis d'environ 60 ans d'âge en Suisse au sud des Alpes. La coupe de taillis s'est faite par l'élimination de tous les arbres vivants et morts. Un inventaire des rejets de souche a été réalisé après deux, respectivement quatre ans afin d'analyser la croissance et la mortalité du nouveau peuplement et de vérifier les facteurs influençant la capacité à rejeter de souche. La mortalité des souches est de $4 \%$, le nombre de rejets par souche (48) est élevé et la croissance des rejets remarquable. La structure du peuplement, la densité des souches et la dimension des vieilles souches n'ont pas d'influence négative sur la capacité de production des rejets ou sur la croissance en diamètre et en hauteur de ceux-ci. Par contre on observe que la qualité de la coupe de la souche a un effet positif. En conclusion, la mesure de la hauteur du rejet dominant peut servir comme un indicateur valable de la vigueur de la régénération dans un taillis de châtaignier.

taillis de châtaignier / sylviculture / compétition / mortalité de souches et des rejets

\section{INTRODUCTION}

Chestnut (Castanea sativa Mill.) coppice forests as well as coppice forests with other tree species are widely present in Mediterranean and central Europe $[11,16]$. They were utilised by short rotations (12-20 years) according to local tradition and required assortments (small saw timber, small poles, fuelwood) which were used for agriculture and domestic demand. During the 1960s and 1970s these traditional small dimension mass products from chestnut coppices progressively lost their economic importance [28]. At present, in several European regions, many chestnut coppices are abandoned or managed simply with extended rotation periods in order to get assortments of larger dimensions.

The problems with ring shake [24], the appearance of chestnut blight [15] and the uncertainty concerning the management of chestnut coppice forests, have all contributed to the present situation.

However studies on treatment of chestnut coppice forests from France and Italy show that with an appropriate treatment, with suitable rotation periods and with purposeful selection and thinning, economically interesting results can be achieved on good sites. The present study of the sprouting ability deals with the first step of a development which is crucial for the planned silvicultural experiment on this and two others study sites.

In France, Bourgeois [7, 9] defined production goals, e.g., "stem timber" ("grumes") and "sleepers" ("billes"). Those products can be promoted by thinning when the plus trees reach $11-12 \mathrm{~cm}$, by reducing the shoots to one per stool [37]. However, the efficacy of this practice has not been scientifically demonstrated yet. In Italy, two to four shoots per stump are always left [1]. Some recent research dealing with ring shake,

* Corresponding author: fulvio.giudici@wsl.ch 
especially of the "crack" type [23], show that a regular [14, 29] and sustained [25] ring growth can reduce ring shake occurrence. By means of repeated thinning the production of quality timber seems to be possible, without having a negative impact to the stability and to the ecological balance of the stands [17]. Some silvicultural models have already been defined and experimental trials have been established to study the effect of thinning on crown development and growth [28]. This kind of intensive production is based on the idea of utilising the existing potential of the stands, e.g., their sprouting ability and growth potential.

Thus, by coppicing, the stand will be completely regenerated with new, quick growing shoots.

It appears to be common knowledge of coppice forests that the dimensions and the age of the stools seem to be significant for the number of active proventive buds. For beech, but not for oak and chestnut, Piussi [32] remarks that the age and consequently the thickness of the bark reduces the possibility of a stool to emit new shoots. Aymard and Fredon [2] used a phytocide marker, and Carlier [13] a radioactive marker, to analyse the root system functionality and thus demonstrate on chestnut stools that a root preferentially nourishes one specific shoot or a shoot group, known as "bouton" (a kind of "panicle") in French [5]. In an aged coppice this suggests that the localisation of the existing stools could play an important role because of the competition exerted by the root systems of adjacent stools. In each case the competition at the stand level (between stools) as well at the stool level (between shoots) implies a progressive reduction (= mortality) of the number of individuals with time. When this occurs, the roots which are not used any more by dead shoots can be exploited by the remaining shoots.

The ageing or the declining vitality of the stools do not seem to be limiting factors for the sprouting ability [19]. At least in more or less regularly managed chestnut coppices the study of Bedeneau and Pages [5] confirms the wide experience made in the chestnut tree zone: the chestnut tree can bear coppice forest management without a loss of vitality. This study shows that the root age of the chestnut tree corresponds approximately to that of the shoots and not to the age of the stump as is the case in e.g., birch. Aymard and Fredon [2] show that, depending on the age of a chestnut stump, the roots are at the disposal of all or a part of the shoots, so that the nutrients coming through the stump can under certain circumstances be put at the disposal of the remaining shoots if some shoots are removed.

The main question treated in this first study is to analyse whether the sprouting ability of the stools in aged coppices provides enough shoots to guarantee the next generation of a chestnut forest, and whether there are enough shoots of good quality for a later selection thinning. The aim of this paper is to quantify, on homogeneous site conditions, the stool mortality and their sprouting ability, to evaluate the shoots vitality in terms of height and diameter growth four years afters coppicing and to verify the role of some factors influencing the sprouting ability.

\section{MATERIALS AND METHODS}

\subsection{Experimental site}

In Switzerland, south of the Alps the sweet chestnut, Castanea sativa Mill., is still the most common tree species: $21 \%$ of the trees

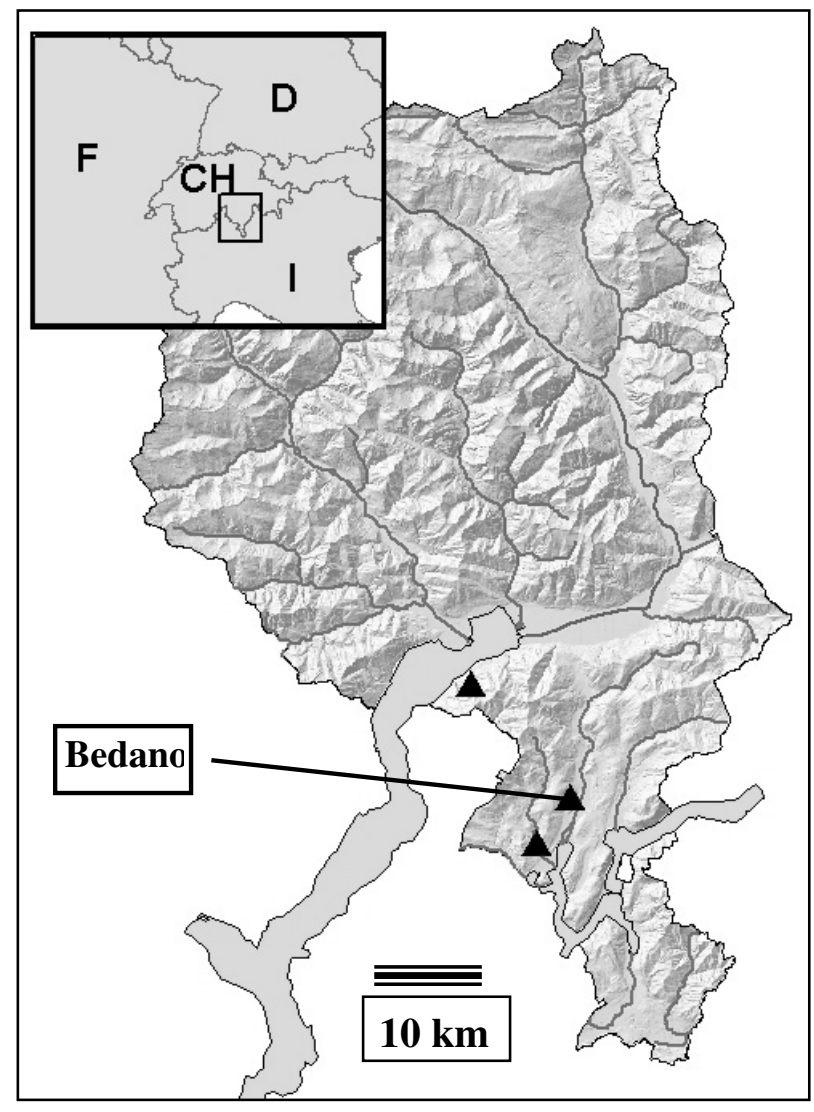

Figure 1. Localisation of the study site Bedano.

covering over 26000 ha in the low altitude and sub-montane belts up to $1000 \mathrm{~m}$ a.s.1. [20]. According to the Swiss National Forest Inventory data [38], 18500 hectares of the total 19800 hectares of the chestnut coppice forests are on productive sites; 10000 hectares are easily accessible and 7800 hectares are located on gentle slopes [26]. The owners are interested to increase the value of these abandoned coppices through new management concepts. To verify the silvicultural methods able to produce high quality lumber, the project "Production of Commercial Timber in Chestnut Coppice Forests" was started in 1997 in southern Switzerland. In this context three study areas were defined: the experimental site Bedano, in Canton Ticino (Fig. 1) from were the data in this study originate is described in Table I.

\subsection{Measurements and observations of the previous stand generation}

The study area of 1.35 ha was subdivided into 9 subplots of 800 $1000 \mathrm{~m}^{2}$ each. These subplots are separated by strips of $5 \mathrm{~m}$ and surrounded by a border strip, forming together subplot 10 . The original stand was surveyed completely according to the measurement scheme of the Growth and Yield research group of the Swiss Federal Research Institute WSL described in [3] and [39]. The location of each stool and each shoot was recorded with co-ordinates. All stools and shoots were numbered.

The social position of all chestnut stools was visually characterised according to Pividori [33] and Macchioni and Pividori [29]. The classes considered were (1) "dominant" (high number of shoots in the upper story with large dimensions); (2) "co-dominant" (some shoots in the upper story with fairly large dimensions); (3) "dominated" (stool with few and small shoots in state of decay); (4) "suppressed" (all 
Table I. Description of the experimental site Bedano.

\begin{tabular}{lc}
\hline Characteristics & Experimental site Bedo \\
\hline Community, local name & Bedano, Bedo \\
Plot No. & $46-016$ \\
Study area & $13553 \mathrm{~m}^{2}$ \\
Geographical position & $46^{\circ} 03^{\prime} \mathrm{N}, 8^{\circ} 54^{\prime} 50^{\prime \prime} \mathrm{E}$ \\
Altitude & $530 \mathrm{~m}$ a.s.l. \\
Aspect & E-SE \\
Relief & Even slope \\
Slope & $20-50 \%$ \\
Soil type & Dystric Regosol, Humic Cambisol [22] \\
Plant association & Cruciato glabrae-Quercetum castanosum ${ }^{2}$ \\
Annual mean precipitation & 1733 mm ${ }^{1}$ \\
Annual mean temperature & $11.3^{\circ} \mathrm{C}^{1}$ \\
Former management & Coppiced in $1942-1945$
\end{tabular}

${ }^{1}$ Climate station Lugano (273 m): source Meteoswiss (period 19011990).

${ }^{2}$ According to [21].

shoots dead, but with yet small live sprouts at the stem basis) and (5) "dead" (all shoots dead, no live wooden matter is visible).

The original stand was removed completely in February-March 1998 by means of a coppice cut. The instruction to the workers was according to the traditional rules [12] - to cut cleanly, regularly and as inclined and as low as possible.

\subsection{Measurements of the new coppice generation}

Two years after coppicing in February 2000, the survival of each chestnut stool and the height of the dominant shoot (i.e., the highest shoot from each stool), as well as the presence of visible damages (forks, cankers, wounds caused by ungulates) were recorded. On randomly selected 63 stumps, stool diameters, $\mathrm{d}_{1.3}$, and height of the new shoots were measured. The number of new shoots higher than $1.0 \mathrm{~m}$ and the number of the new produced shoot groups per stump were therefore recorded and their height (total and of the first year) measured. Their origin, "typical shoots" emitted from visible stool parts or "suckers" (i.e. shoots that rise adventitiously from roots) were recorded too. Four years after coppicing in March 2002, the survey on the 63 stools was repeated.

\subsection{Stool characteristics}

Supposing that the specific site and growth situation of each stool could influence the water and nutrient availability and consequently also its sprouting ability, we characterised the form of the relief in the $2 \mathrm{~m}$ circular area surrounding a stool considering the local micro topographic condition in three classes: hump $(1=A)$, depression $(2=U)$ and regular slope $(3=/)$.

The "cutting quality" was evaluated by means of a 10 classes score from "bad" (very irregular, rough and horizontal cut surface $=1$ ) to "sufficient" (rather regular, waveless and partially inclined cut $=6$ ) until "perfect" (good, clean, plain, regular and inclined cut $=10$ ). In addition we measured the cutting height (average between superior and inferior distance soil-stool cut level) and the circumference of the stool at soil level (girth of the stool area i.e., the external perimeter surrounding all old shoots). As derived variables, the dimension of the stools were analysed considering the old shoot population, as well the occupation area of the stool (area of the ellipse surrounding all cut shoots (in $\mathrm{m}^{2}$ ), the sum of shoot girths (sum of girth of the trees or shoots of a stool in $\mathrm{cm}$ ) and the total stool basal area (sum of all the basal area of all trees or shoots in $\mathrm{cm}^{2}$ ). The competitive status of a stool was derived from the calculated horizontal distance (from centre to centre) from the first to fifth nearest stool.

\subsection{Data analysis}

To detect the factors which influence the sprouting ability of a stool, we used a General Linear Model with backward exclusion of the variables (software SYSTAT 10). An autocorrelation matrix showed that the stool occupation area and the sum of girth are highly correlated with the girth of the stool and the basal area. Therefore they were not taken into the model. The cutting quality was transformed into a variable with three levels and put into the model as a dummy variable.

The relationship between height of the dominant shoot on a stool and the average height of the whole shoot population was analysed to evaluate its suitability as an indicator of the vigour of regeneration in a chestnut coppice.

\section{RESULTS}

\subsection{Characterisation of the original coppice stand}

As shown in Table II, the former stand was a pure chestnut coppice. Less than $2 \%$ of the trees and of the basal area were species other than chestnut.

Table II. Stand data from the original stand (values per hectare, diameter threshold $=8 \mathrm{~cm}$ ).

\begin{tabular}{|c|c|c|c|c|c|c|c|c|c|c|c|c|c|c|c|}
\hline \multirow[b]{2}{*}{ Species } & \multicolumn{9}{|c|}{ Live trees } & \multicolumn{6}{|c|}{ Dead trees } \\
\hline & $N$ & $\begin{array}{c}h_{\mathrm{dom}} \\
(\mathrm{m})\end{array}$ & $\begin{array}{l}d_{\mathrm{dom}} \\
(\mathrm{cm})\end{array}$ & $h / d_{\mathrm{dom}}$ & $\begin{array}{c}h_{\mathrm{g}} \\
(\mathrm{m})\end{array}$ & $\begin{array}{c}d_{\mathrm{g}} \\
(\mathrm{cm})\end{array}$ & $h / d_{\mathrm{g}}$ & $\begin{array}{c}G \\
\left(\mathrm{~m}^{2}\right)\end{array}$ & $\begin{array}{c}V_{7} \\
\left(\mathrm{~m}^{3}\right)\end{array}$ & $N$ & $\begin{array}{l}h_{\mathrm{g}} \\
(\mathrm{m})\end{array}$ & $\begin{array}{c}d_{\mathrm{g}} \\
(\mathrm{cm})\end{array}$ & $h / d_{\mathrm{g}}$ & $\begin{array}{c}G \\
\left(\mathrm{~m}^{2}\right)\end{array}$ & $\begin{array}{c}V_{7} \\
\left(\mathrm{~m}^{3}\right)\end{array}$ \\
\hline Chestnut & 717 & 19.6 & 41.4 & 47 & 17.4 & 26.9 & 64 & 40.6 & 303 & 350 & 13.1 & 13.3 & 99 & 4.5 & 31 \\
\hline Other broadleaves ${ }^{1}$ & 15 & & & & & 16.4 & & 0.6 & 5 & 6 & & 10.5 & & 0.2 & 1 \\
\hline
\end{tabular}

${ }_{1}^{1}$ Fraxinus excelsior L., Acer pseudoplatanus L., Populus tremula L., Betula pendula Roth., Alnus glutinosa (L.) Gaertn., Tilia cordata Mill., Prunus avium (L.) L., Sorbus aria (L.) Crantz. 
Table III. Stool density per hectare and vitality of the original coppice stand.

\begin{tabular}{|c|c|c|c|c|c|c|c|}
\hline \multirow{3}{*}{ Plot No. } & \multirow{3}{*}{$\begin{array}{l}\text { Total stools } \\
\left(\mathrm{n} \mathrm{ha}^{-1}\right)\end{array}$} & \multirow{3}{*}{$\begin{array}{l}\text { Other species } \\
\quad\left(\mathrm{n} \mathrm{ha}^{-1}\right)\end{array}$} & \multicolumn{5}{|c|}{ Chestnut stools $\left(\mathrm{n} \mathrm{ha}^{-1}\right)$} \\
\hline & & & \multirow{2}{*}{ Total } & \multirow{2}{*}{ Live } & \multicolumn{3}{|c|}{ Dead stools } \\
\hline & & & & & Total & Apparently dead ${ }^{1}$ & Really dead $^{2}$ \\
\hline 1 & 577 & 16 & 561 & 506 & 55 & 16 & 40 \\
\hline 2 & 461 & 31 & 430 & 375 & 55 & 16 & 39 \\
\hline 3 & 359 & 38 & 321 & 283 & 38 & 15 & 23 \\
\hline 4 & 351 & 0 & 351 & 312 & 39 & 20 & 20 \\
\hline 5 & 472 & 30 & 442 & 344 & 98 & 39 & 59 \\
\hline 6 & 506 & 0 & 506 & 360 & 146 & 49 & 97 \\
\hline 7 & 527 & 48 & 479 & 412 & 67 & 19 & 48 \\
\hline 8 & 601 & 0 & 601 & 407 & 194 & 74 & 120 \\
\hline 9 & 673 & 10 & 663 & 495 & 168 & 59 & 109 \\
\hline 10 & 458 & 12 & 447 & 352 & 95 & 14 & 80 \\
\hline Stand & 489 & 18 & 471 & 382 & 93 & 28 & 65 \\
\hline$\%$ & & & 100 & 80.3 & 19.7 & 5.9 & 13.8 \\
\hline
\end{tabular}

${ }^{1}$ Social position 4: All shoots dead but on the stem basis there were some small live sprouts (Fig. 8).

${ }^{2}$ Social position 5: All shoots were dead (no visible live wooden matter).

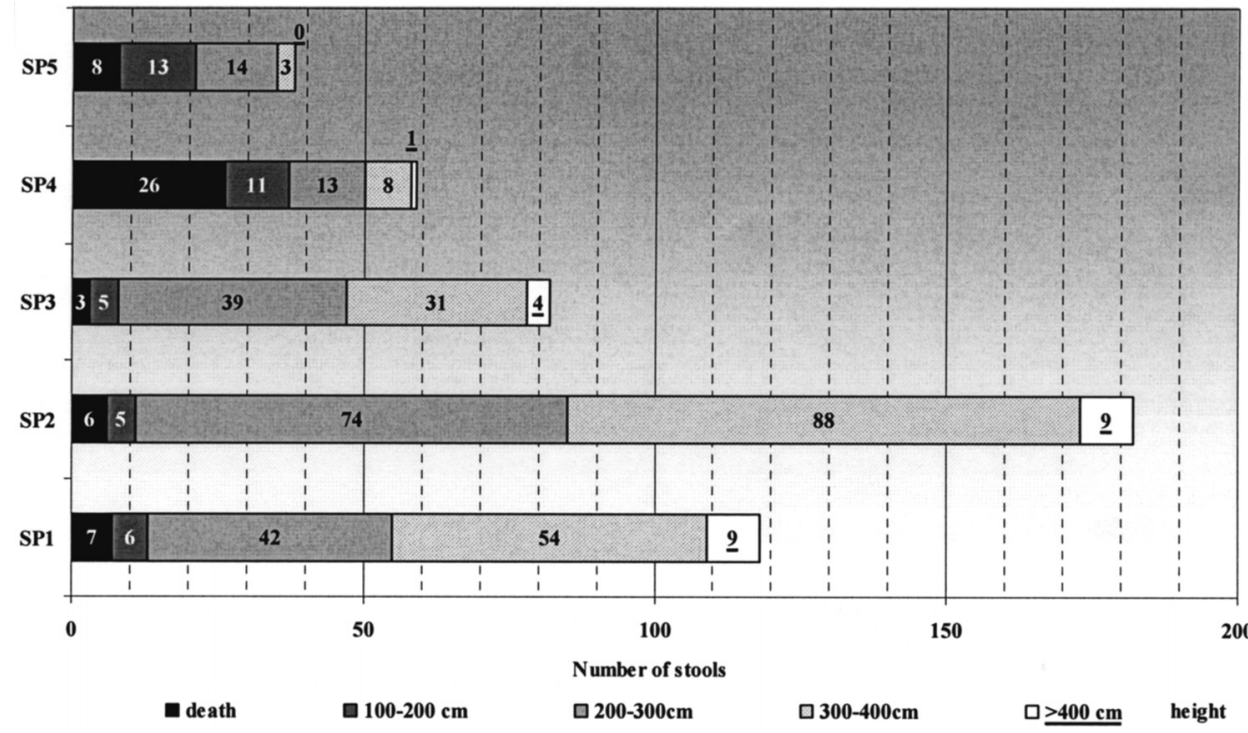

Figure 2. Number (absolute) and status (height after 2 years) of the new dominant shoots relative to the social position (SP) of its own stool before coppicing.
There were no clear traces of former utilisation (thinning etc.). The age of the stand was generally 58 years (cutting year 1940), but a small area in the northern part (plots 8 and 9) was probably coppiced again 11 to 12 years later. The total basal area was $46 \mathrm{~m}^{2} \mathrm{ha}^{-1}$ and the standing volume (merchantable timber) $340 \mathrm{~m}^{3} \mathrm{ha}^{-1}$ [27]. Approximately $10 \%$ (basal area) of the standing trees were dead. The total yield including branches and small wooden material was estimated at $373 \mathrm{~m}^{3} \mathrm{ha}^{-1}$ which results in an estimated mean annual increment $\mathrm{I}_{\mathrm{V} 70-\mathrm{t}}$ of $6.4 \mathrm{~m}^{3} \mathrm{ha}^{-1} \mathrm{a}^{-1}$.

For the whole stand the stool density was $489 \mathrm{ha}^{-1}$ (Tab. III). It was higher in the subplots 8 and 9 due to an additional cop- picing. Before coppicing $13.8 \%(7 \%-20 \%)$ of the chestnut stools did not show live parts, and a further $5.9 \%(2.8 \%-12.3 \%)$ showed only dead shoots and at least one small and short live sprout on the bottom of the stems.

\subsection{Stool survival and recovery}

After two years all 479 chestnut stools were checked. As shown in Figure 2 the stool mortality (i.e., without production of new shoots during the first 2 years) was $10.6 \%$ (50 stools), but only $4.1 \%$ in stools with live shoots before coppicing (social positions 1 to 3 ). Interestingly $56 \%$ of the stools which showed 


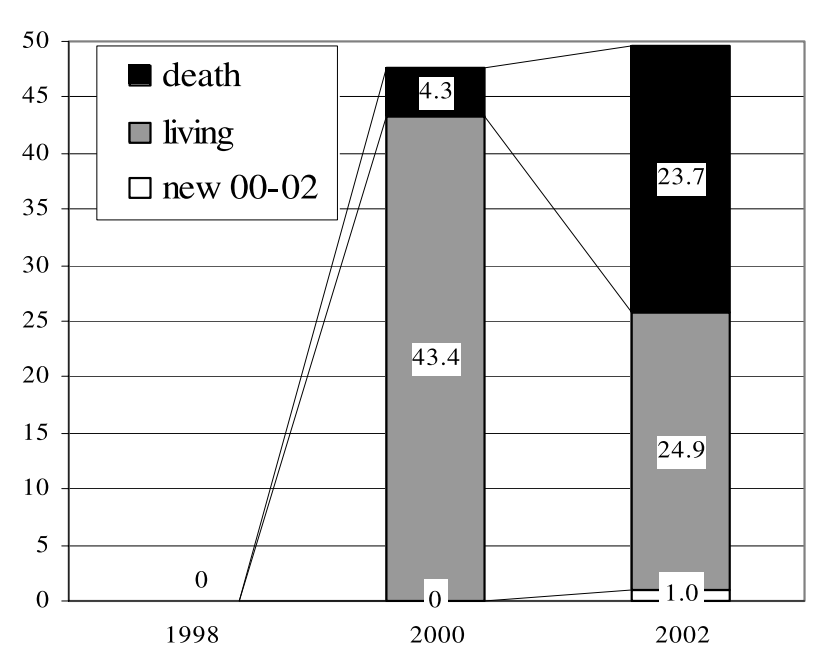

Figure 3. Mean number of shoots per stool 2 and 4 years after coppicing.

only a few small sprouts (social position 4) and even $79 \%$ of the stools without visible live biomass (social position 5) showed live shoots two years after coppicing. In 17 cases, these "apparently dead stools" showed very vigorous 2-year old shoots, longer than $200 \mathrm{~cm}$ and in 3 cases even $300 \mathrm{~cm}$.

\subsection{The new coppice generation}

\subsubsection{Number of shoots and shoot mortality}

The number of shoots higher than $1 \mathrm{~m}$ produced per stool was $47.8 \pm 29.6$ (mean \pm standard deviation) after two years. Within the following two years, each stool produced on the average 0.95 new shoot. Only three stools showed more than five new shoots. After two vegetation periods, $8.0 \%$ of the shoots $(=4.3$ per stool) were dead. Only $43.4( \pm 26.3)$ live shoots remained (Fig. 3). After four years only $24.9( \pm 14.8)$ shoots per stool survived, i.e., a total mortality of $48.7 \%$. This value does not include the high number of small sprouts shorter than one meter which already died during the first 2-year period.

The number of produced shoots was higher on stools with a higher former social position (1 or 2) than on stools with a former social position 3 to 5 , but there were big variations. A $t$-test showed no significant differences between the different social positions.

\subsubsection{Type and groups of shoots}

From the $48.6 \pm 29.3$ shoots produced per stool after 4 years, $4.8 \pm 3.6$ were root shoots (suckers), i.e., they did not originate from visible bark tissue of the stool but sprouted from the soil. Consequently $45.0 \pm 28.0$ shoots were produced by proventive or adventitious buds activated by coppicing.

These new shoots were not distributed evenly over the stool surface covered with bark, but clustered. The average number of groups per stool was $7.6( \pm 3.5)$, ranging between 2 and 16 . The number of clusters was strongly correlated with the total number of emitted shoots (linear regression, $y=0.7654 x^{0.5926}$, with $\left.r^{2}=0.68\right)$. The mortality inside the stool is correlated neither with the number of groups of shoots nor with the size of the groups.

As shown in Figure 4, the live shoots were generally grouped in relatively small groups (3-5 shoots per group) as well as in larger groups with $7-10$ shoots.

\subsubsection{Growth and competition of the new shoots}

The height and diameter growth of the young shoots is considerable. After two vegetation periods, the dominant shoots

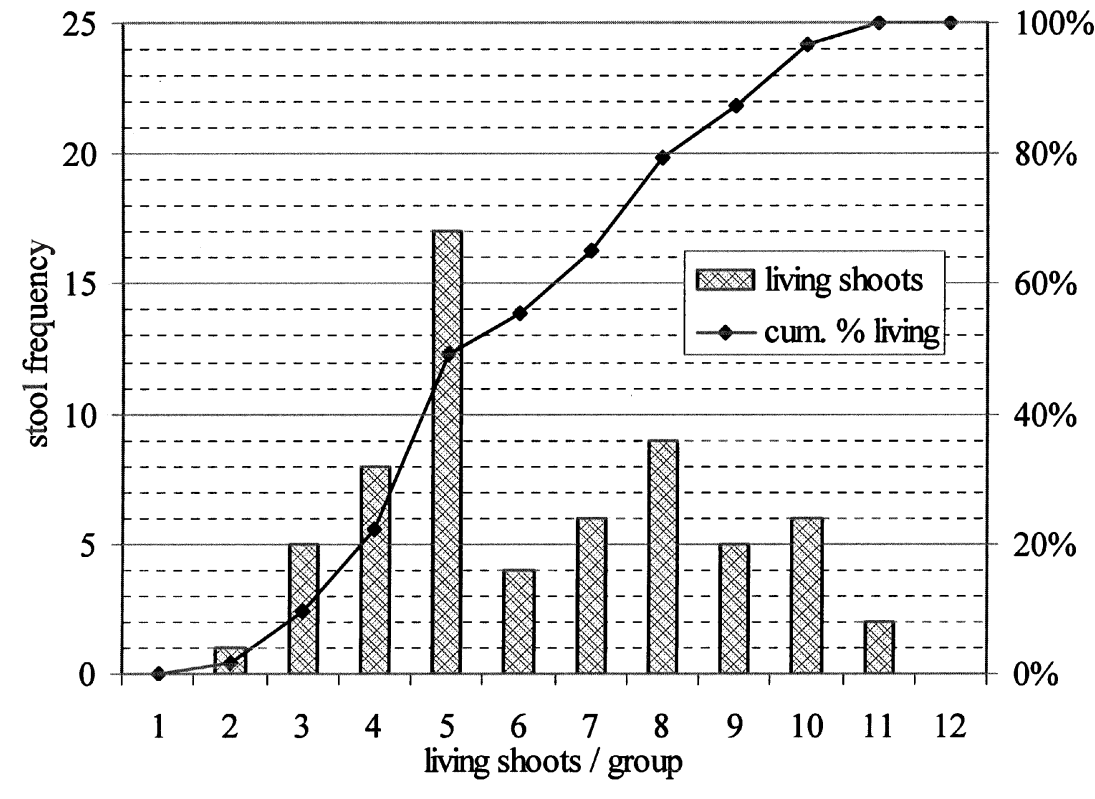

Figure 4. Frequency of the stools in relation to the group size (number of live shoots per group): frequency of live stools (left axis and box) and cumulative percent (right axis, dark line). 25 stools $(=40 \%)$ show 4 or 5 and 15 stools $(=25 \%) 7$ or 8 shoots per group. 


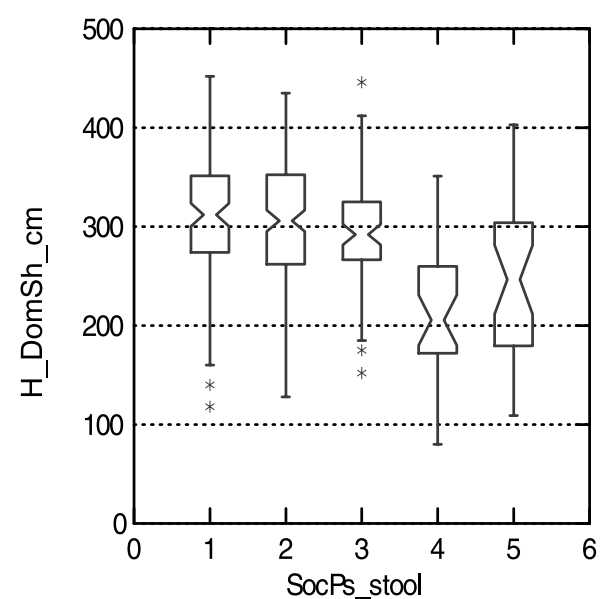

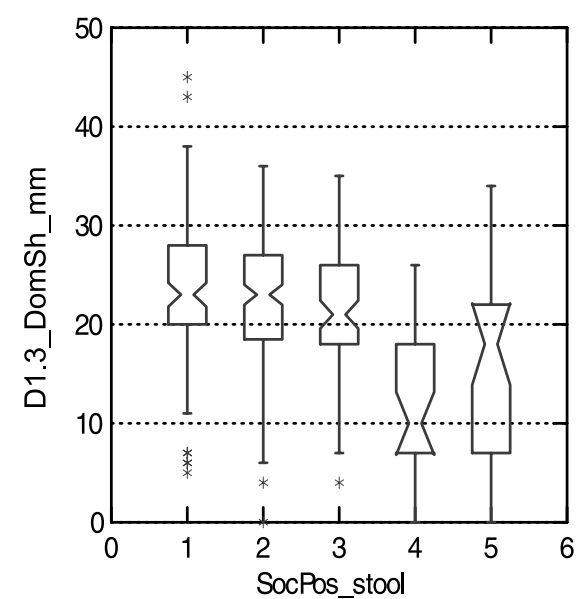

Figure 5. Boxplots of height (left, in $\mathrm{cm}$ ) and diameter (right, in $\mathrm{mm}$ ), of the dominant shoots on the stool two years after coppicing relative to the social position of the stool (SocPos_Stool) before coppicing. On top the number of observations. reached $2.64( \pm 1.10) \mathrm{m}$ in height and $2.13( \pm 0.76) \mathrm{cm}$ in diameter $\mathrm{d}_{1.3}$ (Fig. 5). A Tukey multiple comparison shows that not only on dominant and co-dominant stools (social position 1 and 2) but also on the dominated stools (social position 3 ) height and diameter of the dominant shoots were significantly greater than on the suppressed stools (social position 4). This growth rate was maintained during the following two years: average length and $\mathrm{d}_{1.3}$ after 4 years were $4.76( \pm 1.11) \mathrm{m}$ and $4.06( \pm 1.44) \mathrm{cm}$ respectively. After four years, $15 \%$ of the dominant shoots were higher than $6 \mathrm{~m}$, corresponding to an average annual height increment of at least $1.50 \mathrm{~m}$.

Therefore the competition in the first years is very dynamic. Length and diameter of the dominant shoots at ages 2 and 4 were not strongly correlated (Pearson correlation, $r^{2}=0.556$ for $\mathrm{h}$ and $r^{2}=0.418$ for $\mathrm{d}_{1.3}$ ). Thus more than $57 \%$ of the dominant shoots changed their social position between the first and the second survey.

A linear regression model of annual height growth of dominant shoots explained only $20 \%$ of the variation (adjusted multiple $R^{2}=0.204$, data not shown). The average distance to the five closest neighbouring stools was the only variable retained. The model of annual diameter growth results in $17 \%$ (adjusted multiple $R^{2}=0.171$ ) using stool size (basal area of the shoots of the former stand), cutting height and the average distances to the three and two closest neighbouring stools (data not shown). These results indicate that after four years competition between stools is not yet an important factor for the growth of the new shoot generation.

\subsubsection{Factors influencing the sprouting ability}

\subsubsection{Micro topography}

The box plots in Figure 6 show that the micro-topographic growth conditions of the stools do not significantly influence the number of shoots produced per stool, the height and the diameter of the dominant shoot and the number of shoot groups. Nevertheless, the size of the stools (quantified as total basal area before coppicing) seems to be higher on humps, although the variations are large.

\subsubsection{Stool dimensions}

The numbers of emitted shoots and of live shoots on a stool depend on the basal area of the stool before coppicing (Fig. 7). Parameter estimates for exponential relationships are $y=1.386$ $x^{0.5071}$ for all shoots, and $y=0.9127 x^{0.4707}$ for the live shoots only. The correlation between the number of shoots per stool vs. occupation area of the stool is better $\left(r^{2}=0.522\right.$ for all shoot and 0.440 for the live ones, data not shown). It seems that there is no loss of vigour: all 12 stools occupying $2 \mathrm{~m}^{2}$ or more (corresponding to a $0.8 \mathrm{~m}$ large stool) produced more than 60 new shoots higher than $1 \mathrm{~m}$. The stool size is correlated with the former social position (61\%).

\subsubsection{Stool density}

The average distance to the closest stool is $2.75 \mathrm{~m} \pm 1.00$, to the fifth $4.47 \mathrm{~m} \pm 1.00$, the second, third and fourth stools lie between these values. The number of shoots per stool and these distances have a weak positive correlation $\left(r^{2}=0.28-\right.$ 0.29). The distance to the closest five neighbouring stools shows no correlation with the number of shoots which appeared between the years 2 and 4 after coppicing.

\subsubsection{Cutting quality}

The workers who executed the coppicing were instructed to perform an accurate and low stool cut. A check of the stools showed that it was not possible to cut the stumps close to the ground. The average stool height varied between 2 and $50 \mathrm{~cm}$ (mean $16.6 \mathrm{~cm} \pm 10.7$ ), but the cutting quality was good (mean $6.7 \pm 1.7$, values between 4 and 10).

Smaller stools can generally be cut lower then larger ones, therefore the stool height was positively correlated with the stool size $\left(y(\mathrm{~cm})=0.4092 x^{0.5239}, x=\right.$ basal area in $\mathrm{cm}^{2}, r^{2}=$ $0.435)$. During the first four years the stool height influenced the shoot mortality $\left(r^{2}=-0.118\right)$. 

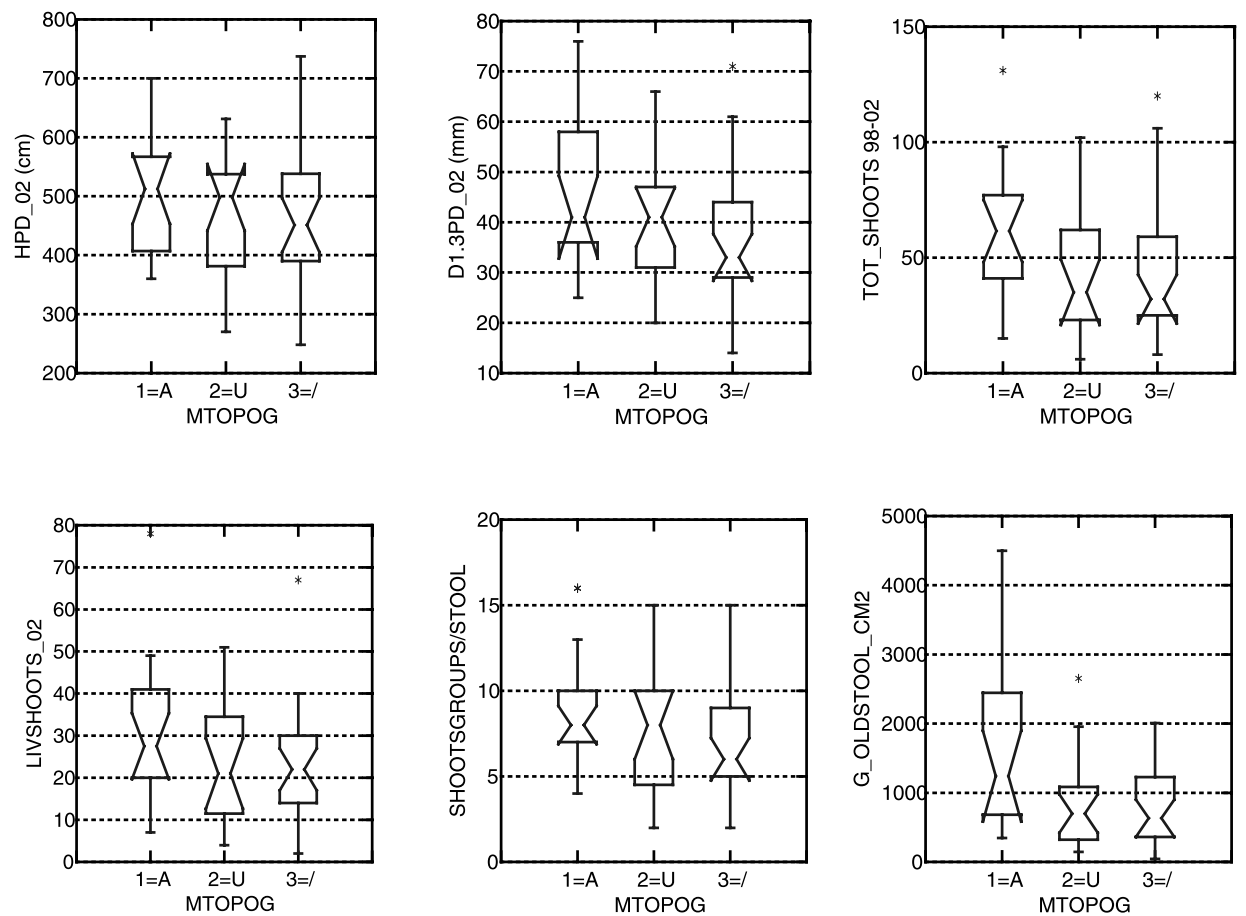

Figure 6. Height of the dominant shoots (left), $\mathrm{d}_{1.3}$ (middle) and total number of produced shoots (right) depending of the micro-topography: hump $(1=A)$, depression $(2=U)$ and slope $(3=/)$. The second row shows the data for the live shoot population, the shoot groups and the basal area of the former coppice generation. Number of observations $=429$.

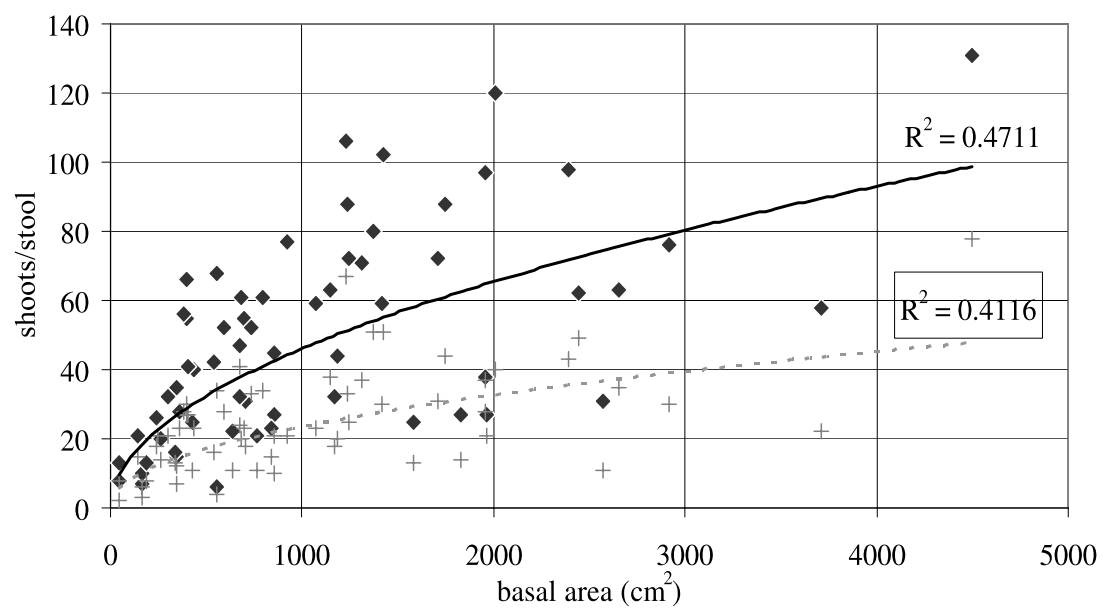

Figure 7. Number of shoots per stool in relation to the basal area of the whole stool (all shoots = squares and solid line; live shoots only = horizontal crosses and dashed line). The functions are exponential relationships. Parameter estimates are given in the text.

\subsection{Shoot quality}

$31.1 \%$ of the dominant shoots on the 429 checked live stools were damaged after two years: $29.3 \%$ were forked, $1.1 \%$ cankerous and $0.7 \%$ wounded by ungulates. Damage proportions for each subplot varied between $18.9 \%$ and $39.3 \%$ for the total damage and between 18.2 and $36.1 \%, 0$ and $3.6 \%$ and 0 and $2.2 \%$ respectively for forks, cankers and ungulate damage. The presence of forks and of canker (after 2 years the infections were still superficial) did not significantly influence the height and diameter.

\subsection{Dominant shoots as indicator for the stool vitality?}

The analysis of the various groups of highest shoots shows that the height and the diameter at breast height of the dominant shoot, i.e. the longest shoot per stool, is a good indicator for the mean height or diameter of a shoot population existing on a stool. The same applies to shoot diameter. In fact there is a linear function $y=\mathrm{a} \times x$ with: $y=$ mean height of the shoot population in $\mathrm{cm}$ and $x=$ height in $\mathrm{cm}$ of the dominant shoot (Tab. IV). Example: the mean height of the 3 highest shoots of a stool corresponds to $96 \%$ of the height of the dominants shoot, $87.2 \%$ for the 10 highest etc.

\subsection{Model for the re-sprouting ability of chestnut coppice}

The number of shoots present on the stools four years after coppicing has been considered as an indicator for the re-sprouting ability. A global model explaining the re-sprouting ability of the stools built on the available data, explained $63 \%$ of the 
Table IV. Correlation between the height and diameter of the dominant shoot (e.g., the longest shoot on a stool after 2 years) and the average height of other shoots on a stool. The coefficient "a" of the linear function is indicated (e.g.: $\mathrm{h}_{[1.3]}=\mathrm{h}_{[\text {dominant shoot] }} \times 0.960$ ).

\begin{tabular}{ccccc}
\hline \multirow{2}{*}{ Relation of the height of the dominant shoot on stool } & \multicolumn{2}{c}{ Height of shoot } & & \multicolumn{2}{c}{ Diameter 1.3 of shoot } \\
\cline { 2 - 3 } & Coefficient a & $R^{2}$ & 0.988 & \multicolumn{2}{c}{ Coefficient a } \\
\hline vs. first 3 shoots & 0.960 & 0.983 & 0.930 \\
vs. first 5 shoots & 0.930 & 0.978 & 0.874 \\
vs. first 10 shoots & 0.872 & 0.692 & 0.761 \\
vs. mean shoot & 0.700 & 0.969 & 0.929 \\
\hline
\end{tabular}

Table V. Regression model for re-sprouting ability of coppiced chestnut. Dependent variable: NRSHOOTSTO = No. shoots per stool 2002, N: 63, Multiple $R$ : 0.795 , squared multiple $R^{2}: 0.632$. Dummy coding used for categorical variable TFCUTTINGQ (3 levels) (cutting quality transformed).

\begin{tabular}{|c|c|c|c|c|}
\hline \multicolumn{5}{|c|}{ Analysis of variance } \\
\hline Effect & Coefficient & Std error & Std coef. & $P$ \\
\hline Girth of stool & 12.528 & 1.891 & 0.581 & 0.000 \\
\hline Distance to next neighboring stool & 5.392 & 2.428 & 0.184 & 0.030 \\
\hline Cutting height & 1.324 & 0.339 & 0.480 & 0.000 \\
\hline Cutting quality (transformed) & - & - & - & 0.000 \\
\hline Sum-of-squares & $d f$ & Mean-square & $F$-ratio & $P$ \\
\hline Regression & 5 & 6854.266 & 19.615 & 0.000 \\
\hline 19918.383 & 57 & 349.445 & & \\
\hline \multicolumn{5}{|c|}{ Estimates of effects $\mathrm{B}=\left(\mathrm{X}^{\prime} \mathrm{X}\right) \mathrm{X}^{\prime} \mathrm{Y}$} \\
\hline \multicolumn{3}{|c|}{ Number of shoots per stool } & & \\
\hline Constant & & -2.405 & & \\
\hline Girth of Stool & & 12.528 & & \\
\hline Average distance to next neighbor & & 5.392 & & \\
\hline Cutting height & & 1.324 & & \\
\hline Cutting quality (transformed) & 1 & -44.003 & & \\
\hline Cutting quality (transformed) & 2 & -19.229 & & \\
\hline
\end{tabular}

variation (Tab. V). Input variables were girth of the stool, basal area of the shoots of a stool, distance to the next neighbour, cutting height and the transformed cutting quality. The stepwise backward regression excluded only the basal area. That means that the model includes following four variables:

- $\quad$ girth of the stool;

- $\quad$ distance to the closest neighbouring stool;

- cutting height;

- cutting quality.

\section{DISCUSSION}

\subsection{Structure and mortality of chestnut coppice stands}

The stand of Bedano was a simple coppice, i.e., pure chestnut coppice, originating from a coppice cut executed in 1942-1945. The relatively low chestnut stool density $\left(350-500 \mathrm{ha}^{-1}\right.$ in the different subplots) and as a consequence the large spacing between the stools as well as the relatively compacted stool sizes $\left(1.17 \pm 0.36 \mathrm{~m}^{2}\right)$ suggest that the coppice management is relatively recent and that the stand was probably a chestnut orchard until the beginning of the 20th century. Bagnaresi and Giannini, based on a review of chestnut coppices in Italy [4], state that chestnut coppice stands show a dense structure with more than $700-800$ stools ha ${ }^{-1}$ only after 4 or 5 successional coppice cuts.

The absence of visible signs of cuts, the presence of a dense population of dead shoots, especially in the diameter classes below $16 \mathrm{~cm}$ [27] and the high percentage (ca. 20\%) of suppressed or dead stools lead us to suppose that since the last coppicing, the stand followed a "natural" evolution i.e., undisturbed by human activities. This situation demonstrates that during the past decades there was a strong competition between shoots (on the stools) and stools. This competition resulted in a social re-arrangement of the individuals remaining in the former stand and in a rising number of dead shoots and stools [29].

After this long phase of natural development, the coppicing of 1998 was a traumatic event for the stand. After coppicing, 


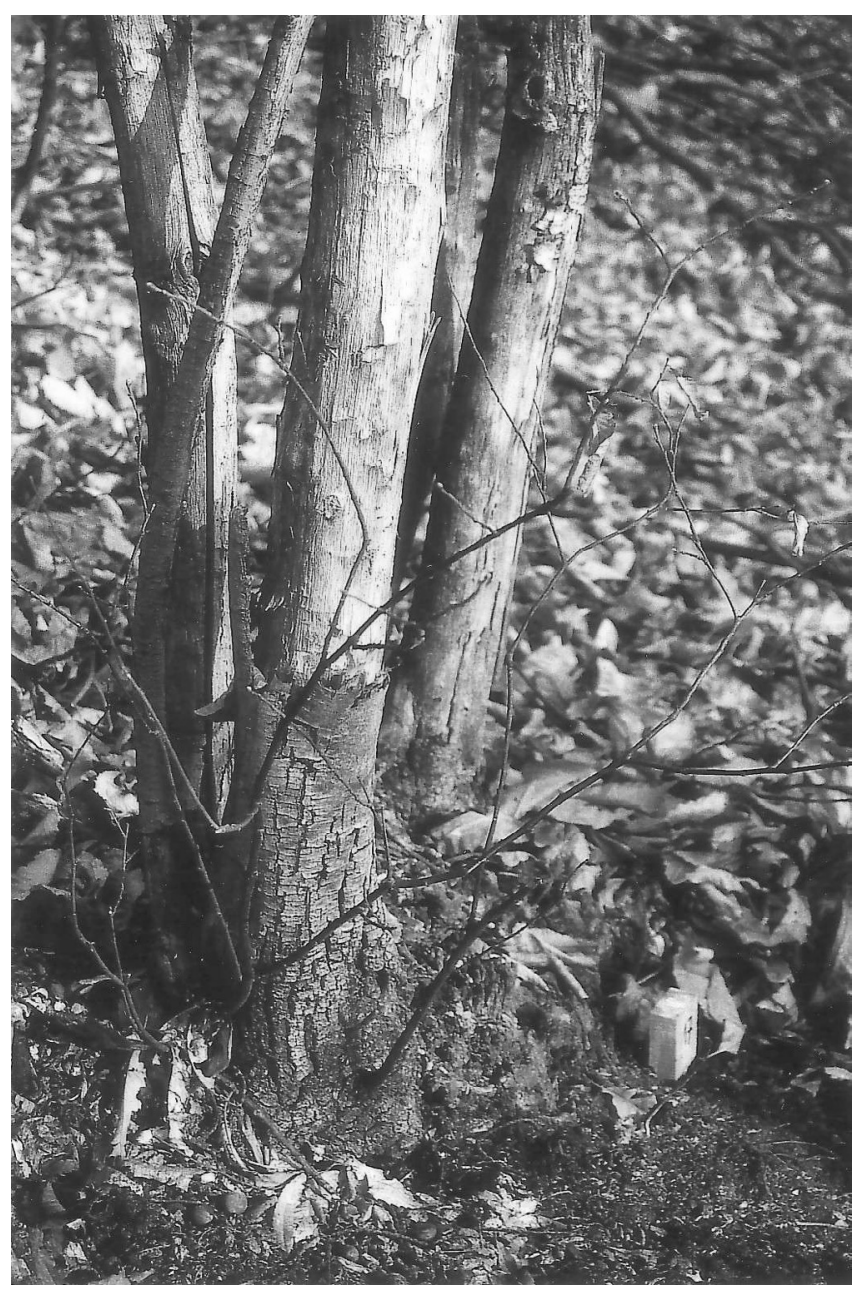

Figure 8. Experimental plot Bedano 9, sweet chestnut stool No. 17, with three dead shoots of 81,84 and $99 \mathrm{~mm} \mathrm{~d}_{1.3}$. Before coppicing we observed at the basis of several dead stools live sprouts, $30-50 \mathrm{~cm}$ long, diameter 4-5 mm. The physiological significance of these sprouts and the formation mechanisms should be investigated.

the competition starts from zero and the social organisation of the coppice stand is reorganised. 24 stools with the social positions 1 to 4 did not sprout at all, but unexpectedly some stools which showed no signs of life began to produce new and in some cases, very vigorous shoots. This has also been observed in other chestnut coppices by Pividori and Motta-Fré [34]. Root anastomosis may explain this phenomenon. In our study we observed that in one third of the stools without live stems, the stools were "only apparently dead". At the stem basis, we observed the presence of small and fine live sprouts (Fig. 8). The physiological significance of these sprouts and the formation mechanisms should be clarified, but we suppose that they are a form of "stand-by" condition, a type of a survival strategy with a minimal metabolic activity assumed by the tree while waiting for better environmental conditions (e.g., a coppicing or a forest fire).

\subsection{Relationships between sprouting ability and stool characteristics of chestnut coppices}

Our results confirm that the spouting ability is positively correlated with the stool sizes and the stool occupation area. This is not surprising because both parameters are correlated with the live bark area and therefore with the probability of finding proventive buds.

Piccioli [31] observed that the stools of chestnut coppice stands maintain their vigour for 150-160 years if the cutting of the shoots is executed correctly. Pividori and Motta-Fré [34] found that the average number of shoots depends on the stool sizes: from 12 shoots produced by a small stool up to 120 from a big one. Bourgeois [8] underlined that very large and old chestnut stools tend to lose the sprouting ability, show a higher mortality of the produced shoots and therefore tend to become exhausted in time. Our coppice has been coppiced only two or tree times and consequently the stools are relatively young, although the number of shoots per stool does not increase linearly with the former basal area of the stool but follows a power function.

Furthermore, we observed neither a relationship between shoot mortality and former basal area nor with their occupation area $\left(r^{2}<\right.$ then 0.04$)$. Nevertheless this question of a possible reduction of the stool vitality over time is still open and can be further investigated on our permanent research plots.

Finally in the first four years the micro-topographic growth conditions of stools as possible indicators for the water absorption ability influence neither the number of produced shoots nor their dimensions (height and diameter).

\subsection{Dynamics of the stand after coppicing}

The emergence of new shoots after coppicing is generally explosive. Piccioli [31] counted all shoots in chestnut coppices, and found local densities of up to 140000 shoots ha ${ }^{-1}$ in the first year. During the first two years after coppicing we observed a high number of shoots too, but the major part of these shoots died during the first or the second year. So we decided to consider only those which have the potential to become silviculturally significant (i.e., higher $>1 \mathrm{~m}$ ). The number of shoots per stool after two years was close to 50 (i.e., ca. $20000 \mathrm{ha}^{-1}$ ) and did not rise in the following two years in which the mortality increased. Four years after coppicing approximately half of the new shoots, especially the small ones, were dead, probably due to high competition. Height and diameter growth during the first years is noteworthy in chestnut coppices: diameter growth up to $19 \mathrm{~mm}$ year $^{-1}$ and height growth up to $185 \mathrm{~cm}_{\text {year }}{ }^{-1}$. It is clear that under these conditions competition for light, water and nutrients is very strong, and consequently mortality high.

As demonstrated in several yield studies of chestnut coppices, the mortality curve has an exponential trend and tends to decrease rapidly. After 8-10 years there are generally 7000 10000 stems ha $^{-1}$ which is sufficient for a silviculture aiming at the production of high quality timber. In Bedano there were approximately 12000 live shoots ha ${ }^{-1}$ after four years. In the free spaces between stools and especially where stools had died, chestnut regeneration from seed was abundant with densities of up to $12000 \mathrm{ha}^{-1}$. Between 4 and 10 years about half 
the shoots will die due to competition [28]. Thus with the first thinning (10-14 years) and a mean frequency of 10-12 shoots per stool, 50-60\% with a dominant social position [31], there will be enough individuals for future thinnings, considering that the silvicultural models for quality timber [1, 7] by age 30-35 foresee between 0.5 and 2 shoots per stool.

\subsection{How do coppiced chestnut stools sprout?}

On coppiced stools the new generation of shoots is produced by the activation of buds situated under the bark. Most of them are generally proventive, i.e., dormant buds. In some cases and especially under stress, the stools can develop new buds, defined as adventitious buds, that can produce "false shoots" [18]. In our study we observe this kind of shoot very rarely and generally they died during the first or the second year. Similar results were found in a younger chestnut coppice in Piedmont [34].

A French research group [30] elaborated a model for chestnut coppice development between 1 and 35 years, which predicts the growth of the shoots as well as their mortality. Their analysis of the role of stand measurements (height, dominant diameter, basal area and volume) as well as structural stand characteristics (number of shoots and stools per hectare) demonstrate the necessity to distinguish two types of coppice stands:

- $\quad$ stands with few stools but with many shoots on each stool;

- $\quad$ stands with a higher stool density but with a low number of shoots per stool.

Chestnut stools do not seem to have a predetermined sprouting pattern. We found that the new shoots are generally organised in small groups of 3-5 or in groups of 7-10 individuals. This kind of structure was described by Rullier-Breval [36], and called "boutons" (a French term meaning panicle), a sort of bundle made of a cluster of sleeping buds. Thus it seems that this kind of clumped distribution of shoots at the stool level (as "bundle" of shoots) reiterate the structural pattern observed at the stand level (as arrangement of stools).

After coppicing, a stool tries to compensate the imbalance between aerial and underground woody mass [35]. The stools i.e., the woody live parts remaining in the stand, with their reserve function represent the key element for the regeneration of the coppice. In fact the chestnut trees will utilise the root system of the former generation to create a new coppice generation. But why did some stools die after coppicing and why is the sprouting ability so variable? The significance of the organisation of the shoots in groups and their dynamics as well as their silvicultural requirements will be investigated in the next years.

\subsection{Factors influencing the sprouting ability of chestnut coppice}

Cabanettes and Pages [10] showed that the cutting height (positive correlation) and the cutting instrument (axe $+5 \%$ and chain saw -20\%) influence the number of produced shoots too. But with the General Linear Model presented here it can be shown that the sprouting ability of the stool probably depends on a complex set of factors, which are exogenous, anthropogenic, as well as of endogenous origin. Exogenous factors (variables describing stand structure, e.g., the sizes of the stools and the distance to the neighbouring stools and consequently the competitive conditions), as well as the cutting characteristics (quality and height) seem to determine to a large measure the sprouting ability of a stool. In this context the importance of cutting the stools close to the ground, regularly and cleanly has been confirmed.

For the third category (not investigated in this study), the factors related with the physiology (physiological age of the stool, genetics, number of existing preventive buds, root development etc.) could play an important role, especially at the ecological limits of the species. Bond and Midgley [6] consider sprouting as a life strategy and underline that for some species this capacity is a helpful resource to regenerate damaged stems or crowns. Thus sprouting can be considered a survival mechanism, a sort of physiological response to minimise the effects of a disturbance (e.g., fire or cutting) and to reduce the turnover, as well as a stratagem for reducing the dependence of a population on seeds for their survival in a given place. In the case of chestnut, the experience gained from coppicing indicates, that if some technical criteria are considered, an "apparently violent" management allows a sustainable profit to be made using the good regeneration ability of the stools.

\section{CONCLUSIONS}

The increasing demand of high quality timber implies an adjustment of the silvicultural methods in the case of chestnut. Regeneration of all chestnut stands by means of coppicing seems to be possible, even those which have been abandoned for decades. The good sprouting ability of chestnut stools guarantees an adequate production of vigorous shoots. The results from this case study reveal practical significances:

- A stool is a functional entity as well as the productive entity of a chestnut coppice. Therefore a stool has to be treated according to well defined rules: regular cut, with a concave or inclined form, as low as possible and a clean cut (i.e., with a sharp chain saw).

- Shoot selection in the first 3-4 years is not useful as a tending measure since growth dynamics and the mortality are very high. This makes it very difficult to identify the qualitatively promising shoots which will form the main structure of the up-growing part.

- For the evaluation of the sprouting ability of a chestnut coppice stand it is not necessary to measure a lot of shoots. The length and diameter of the dominant shoot on a stool is representative for the rest of the sprouts on a stool.

Acknowledgements: The authors acknowledge the technical assistance of Franco Fibbioli, Enrico Cereghetti, Christian Matter, Karl Siegrist and Larissa Peter for the field measurements. Contributions during the surveys and the data analysis were provided by Bernhard Ramp, Christian Gobbin, Cosma Bonoli and Edgar Kaufmann. For the critical review of the manuscript we sincerely thank Marco Conedera, Peter Brang as well as the two anonymous reviewers. 


\section{REFERENCES}

[1] Amorini E., Bruschini S., Manetti M.C., La sostenibilità della produzione legnosa di qualità dal ceduo di castagno: modello di trattamento alternativo al ceduo a turno breve, in: Convegno nazionale sul castagno, Cison di Valmarino (Treviso), 1997, pp. 217-231.

[2] Aymard M., Fredon J.J., Study of the relationship between roots and coppice shoots in Castanea sativa, Ann. Sci. For. 43 (1986) 351-363.

[3] Bachofen H., Zingg A., Effectiveness of structure improvement thinning on stand structure in subalpine Norway spruce (Picea abies (L.) Karst.) stands, For. Ecol. Manage. 145 (2001) 137-149.

[4] Bagnaresi U., Giannini R., I castagneti da legno in Italia, in: Produttività e valorizzazione dei castagneti da frutto e dei cedui di castagno, Accademia Nazionale di Agricoltura, Bologna, 1979, pp. 145178.

[5] Bedeneau M., Pages L., Study of the growth rings of roots of coppiced trees, Ann. Sci. For. 41 (1984) 59-68.

[6] Bond W.J., Midgley J.J., Ecology of sprouting in woody plants: the persistence niche, Trends Ecol. Evol. 16 (2001) 45-51.

[7] Bourgeois C., Améliorer les taillis de châtaignier, in: le châtaignier : des taillis à ne pas négliger, IDF, 1987, pp. VIII-XV.

[8] Bourgeois C., Le châtaignier : un arbre, un bois, Paris, IDF, 1992, $367 \mathrm{p}$.

[9] Bourgeois C., Le châtaignier : un arbre, un bois, 2e éd., Bourgeois C., Sevrin E., Lemaire J., Eds., Paris, IDF, 2004, 347 p.

[10] Cabanettes A., Pages L., Effet des techniques de coupe sur la croissance et le nombre de rejets dans un taillis de châtaignier (Castanea sativa Mill.), Ann. Sci. For. 47 (1990) 75-86.

[11] Cañellas I., Del Rio M., Roig S. and Montero G., Growth response to thinning in Quercus pyrenaica Willd. coppice stands in Spanish central mountain, Ann. For. Sci. 61 (2004) 243-250.

[12] Cappelli M., Elementi di selvicoltura generale, Edagricole, Bologna, 1991, $389 \mathrm{p}$.

[13] Carlier G., Étude de la sectorisation des souches de châtaignier à l'aide d'eau tritiéee, Ann. Sci. For. 44 (1987) 85-101.

[14] Chanson B., Leban J.M., Thibaut B., La roulure du châtaignier (Castanea sativa Mill.), For. Méditer. 11 (1989) 15-32.

[15] Conedera M., Cancro corticale del castagno: principali caratteristiche epidemiologiche e misure pratiche di controllo, Ber. Eidgenöss. Forsch. Anst. Wald Schnee Landschaft. 335 (1993) 40.

[16] Conedera M., Manetti M.C., Giudici F., Amorini E., Distribution and economic potential of the Sweet chestnut (Castanea sativa Mill.) in Europe, Ecol. Mediter. 30 (2004) 47-61.

[17] Cutini A., New management options in chestnut coppices: an evaluation on ecological bases, For. Ecol. Manage. 141 (2001) 165174.

[18] De Philippis A., Polloni veri, polloni falsi, polloni radicali, L'Italia forestale e montana 1 (1946) 220-222.

[19] Dubroca E., Saugier B., Effet de la coupe sur l'évolution saisonnière des réserves glucidiques dans un taillis de châtaignier, Bull. Soc. Bot. Fr. 135 (1988) 55-64.

[20] EAFV H. (Ed.), Schweizerisches Landesforstinventar: Ergebnisse der Erstaufnahme 1982-1986, Berichte der Eidgenössischen Forschungsanstalt für Wald, Schnee und Landschaft, Birmensdorf, Vol. 305, 1988, 375 p.
[21] Ellenberg H., Klötzli F., Waldgesellschaften und Waldstandorte der Schweiz, Mitteilungen EAFV 48, (1972) 587-930.

[22] FAO (Ed.), FAO-Unesco Soil Map of the World, Revised Legend, with corrections and updates, World Resources, FAO Report 60, Reprinted 1997 with updates as Technical Paper 20, ISRIC, Wageningen, 1988, Rome, $140 \mathrm{p}$.

[23] Fonti P., Macchioni N., Ring shake in chestnut (Castanea sativa Mill.): Anatomical description, extent and frequency of failures, Ann. For. Sci. 60 (2003) 403-408.

[24] Fonti P., Macchioni N., Thibaut B., Ring shake in chestnut (Castanea sativa Mill.): State of the art, Ann. For. Sci. 59 (2002) 129-140.

[25] Fonti P., Sell J., Radial split resistance in chestnut earlywood and its relation to the ring width, Wood Fiber Sci. 35 (2003) 201-208.

[26] Giudici F., La valorizzazione del legname di castagno nel Cantone Ticino, Forestaviva. 13, numero speciale (1995) 81-88.

[27] Giudici F., Zingg A., Capacità produttiva e massa legnosa nei cedui di castagno invecchiati del Sud delle Alpi, Schweiz. Z. Forstw (submitted 2005).

[28] Giudici F., Amorini E., Manetti M.C., Chatziphilippidis G., Pividori M., Sevrin E., Zingg A., Sustainable management of sweet chestnut (Castanea sativa Mill.) coppice forests by means of the production of quality timber, Ecol. Mediter. 26 (2000) 8-14.

[29] Macchioni N., Pividori, M., Ring shake and structural characteristics of a chestnut (Castanea sativa Mill.) coppice stand in norther Piedmont (northwest Italy), Ann. For. Sci. 53 (1996) 31-50.

[30] Pagès L., Cabanettes A., Evolution of the density of sprouts and the structure of stands in sweet-chestnut coppices, Acta OecologicaInt. J. Ecol. 14 (1993) 823-838.

[31] Piccioli L., Boschi cedui, trattamento e prodotti, in Monografia del castagno, Fabbricanti italiani di estratto di castagno, Firenze, 1922, pp. 197-221.

[32] Piussi P., Selvicoltura generale, in : Scienze forestali e ambientali, UTET, Torino, 1995, $421 \mathrm{p}$.

[33] Pividori M., Costruzione di un diagramma selvicolturale per il bosco ceduo di castagno (Castanea sativa Mill.) della collina morenica canavesana (TO), Monti e Boschi. 3 (1995) 12-17.

[34] Pividori M., Motta Fré V., Analisi evolutiva di un ceduo di castagno (Castanea sativa Miller) dopo il taglio di utilizzazione, in: Convegno nazionale sul castagno, Cison di Valmarino, Treviso, 1997, pp. 233-244.

[35] Ries S., Le compartiment racines d'un taillis de châtaigniers du Sud-Ouest de la France ; biomasse, structure et évolution, Université de Grenoble, Grenoble, 1988, 186 p.

[36] Rullier-Breval B., Croissance d'un taillis de châtaignier (Castanea sativa Mill.) après coupe : étude au cours des trois premières années, Université Paris-Sud, Paris, 1985, 155 p.

[37] Sevrin E., Améliorer les taillis de châtaignier, Forêt Entreprise, 97 (1993) 13-17.

[38] WSL, Inventario Forestale Nazionale Svizzero IFN, Elaborazione speciale dei dati 1983-1985 del 25 ottobre 2001, Urs Beat Brändli, Istituto federale di ricerca WSL, Birmensdorf, 2001.

[39] Zingg A., Diameter and Basal Area Increment in Permanent Growth and Yield Plots in Switzerland, in: Growth Trends in European Forests, European Forest Institute Research Report No. 5, H.M. Spiecker K., Köhl M., Skovsgaard J.P. (Eds.), Springer, Berlin, Heidelberg, 1996, pp. 239-265. 